\title{
Classification of Bacteria Nodulating Lathyrus japonicus and Lathyrus pratensis in Northern Quebec as Strains of Rhizobium leguminosarum biovar viciae $\dagger$
}

\author{
PASCAL DROUIN, ${ }^{1}$ DANIELLE PRÉVOST, ${ }^{2 *}$ AND HANI ANTOUN ${ }^{1}$ \\ Recherche Sciences de la Vie et de la Santé, Université Laval, Sainte-Foy, Québec, Canada G1K 7P4, ${ }^{1}$ and Soil and \\ Crops Research Centre, Agriculture and Agri-Food Canada, Sainte-Foy, Québec, Canada G1V $23^{2}$
}

\begin{abstract}
The diversity of two populations of rhizobia isolated from Lathyrus japonicus (30 strains) and Lathyrus pratensis (49 strains) growing in northern regions of Quebec, Canada, was determined on the basis of phenotypic characteristics, multilocus enzyme electrophoresis, DNA-DNA homology, and 16S ribosomal DNA sequencing. According to numerical analysis of phenotypic characteristics, strains were divided into four groups. Strains isolated from L. pratensis fell in groups I to III; the latter included reference strains of Rhizobium leguminosarum. All strains isolated from $L$. japonicus were included in group IV. All strains had nodulation characteristics similar to those of $R$. leguminosarum bv. viciae. Strains isolated from $L$. japonicus originating from an arctic region were usually able to grow at $5^{\circ} \mathrm{C}$ and were more likely to be tolerant to copper $\left(\mathrm{CuCl}_{2} \cdot \mathrm{H}_{2} \mathrm{O}, 100 \mu \mathrm{g} / \mathrm{ml}\right)$ and lead $\left[\mathrm{Pb}\left(\mathrm{CH}_{3} \mathrm{COO}\right)_{2}, 500 \mu \mathrm{g} / \mathrm{ml}\right]$ than strains isolated from L. pratensis from a boreal zone. However, both populations of Lathyrus strains were adapted to the cold in comparison to reference strains from temperate regions. Each population had similar genetic diversity $(H=0.45)$, determined by multilocus enzyme electrophoresis of the loci encoding eight enzymes, but the diversity obtained by analyzing all strains including the reference strains $(H=0.58)$ was higher. Representative strains of both populations showed high levels of DNA homology among themselves and with $R$. leguminosarum. Partial sequences of the $16 \mathrm{~S}$ ribosomal RNA genes were similar to those reported for $R$. leguminosarum bv. viciae. We conclude that the strains isolated from $L$. japonicus and $L$. pratensis belong to $R$. leguminosarum bv. viciae but are distinguishable by growth at $5^{\circ} \mathrm{C}$, which is a characteristic related to their geographic origin.
\end{abstract}

Many Lathyrus species are used for soil cover, green manure, erosion control, and rehabilitation of cutover or burned-over land. Plant species with agronomic potential such as Lathyrus sylvestris (flat pea), Lathyrus tingitanus (tangier pea), and Lathyrus sativus (chickling vetch) used for forage or green manure have been evaluated for their productivity with $\mathrm{N}$ input from $\mathrm{N}_{2}$ fixation $(3,24)$. Microsymbionts from the legume genera Lathyrus, Pisum, and Vicia were named Rhizobium leguminosarum Frank in the first edition of Bergey's Manual of Determinative Bacteriology in 1923. The classification of Lathyrus rhizobia as $R$. leguminosarum was based on the description of bacteroids and on the host nodulation range. These characteristics were similar for Lathyrus, Pisum, Vicia, and Lens species and their rhizobia, and these reciprocal relationships seemed to be restricted within legumes from the tribe Vicieae (1). However, there is no report on the physiological and genetic relationships of Lathyrus rhizobia, while $R$. leguminosarum strains from Vicia or Pisum species have been thoroughly described probably because these symbioses are more agronomically important.

In the last decade, the classification of $R$. leguminosarum was revised with the addition of genetic techniques to the traditional phenotypic characterization. In the Bergey's 1984 edition (9), the three former species $R$. leguminosarum, Rhizobium phaseoli, and Rhizobium trifolii were grouped in a single species, $R$. leguminosarum comprising the biovars phaseoli, trifolii, and viciae. The division of the species in biovars is based

\footnotetext{
* Corresponding author. Mailing address: Soil and Crops Research Centre, Agriculture and Agri-Food Canada, 2560, Hochelaga Blvd., Sainte-Foy (Québec) Canada G1V 2J3. Phone: (418) 657-7980. Fax: (418) 648-2402. Electronic mail address: prevostd@em.agr.ca.

$\dagger$ Contribution 522 of Agriculture and Agri-Food Canada Research Centre at Sainte-Foy.
}

largely on host plant specificity, and accordingly, $R$. leguminosarum bv. trifolii includes strains nodulating clovers, $R$. leguminosarum bv. viciae comprises strains nodulating plant species belonging or related to the tribe Vicieae, such as peas (Pisum spp.) and vetches (Vicia, Lens, and Lathyrus spp.), and $R$. leguminosarum bv. phaseoli includes strains that nodulate beans (Phaseolus spp.). An example of the complexity and the evolution of this classification has been revealed by the heterogeneity among strains of $R$. leguminosarum bv. phaseoli which resulted in the description of two new species: Rhizobium tropici and Rhizobium etli $(12,13,19)$. The presence of such heterogeneity among strains of biovar viciae has not yet been reported.

The aim of our study was to classify rhizobia isolated from two Lathyrus species adapted to the cold conditions in northern Quebec, Canada. One legume species, Lathyrus japonicus (beach pea) is perennial and indigenous to the sandy coasts of Quebec, with a growth range extending from temperate to arctic regions $(11,15)$. The other leguminous species, Lathyrus pratensis (yellow vetchling), is an introduced European species that can grow in relatively cold regions of the boreal forest zone of Quebec (11). The rhizobial strains were characterized according to the minimal standards for the description of new genera and species of rhizobia (8).

\section{MATERIALS AND METHODS}

Bacterial strains. The two populations of rhizobia consisted of 49 strains from $L$. pratensis growing in a field of the Val d'Or region, Quebec, Canada $\left(48^{\circ} 07^{\prime} \mathrm{N}\right.$,

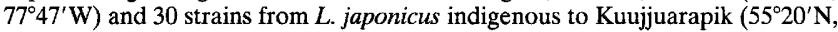
$77^{\circ} 50^{\prime} \mathrm{W}$ ) in the Hudson's Bay arctic zone of Quebec, Canada. Strains were isolated from nodules, and their identities were confirmed by testing their ability to nodulate the trap host species (23). For comparison, 18 reference strains belonging to known species of rhizobia or originating from different plant species were included in the study (Table 1). All strains were maintained on yeast extract-mannitol (YM) agar slants (23) at $4^{\circ} \mathrm{C}$ or as a dense suspension in $10 \%$ (vol/vol) glycerol at $-70^{\circ} \mathrm{C}$. 
TABLE 1. Reference strains

\begin{tabular}{llll}
\hline \multicolumn{1}{c}{ Strain } & \multicolumn{1}{c}{ Species } & \multicolumn{1}{c}{ Host } & \multicolumn{1}{c}{ Source } \\
\hline USDA 191 & Rhizobium fredii & Glycine max & USDA \\
CFN 42 & Rhizobium etli & Phaseolus vulgaris L. & CFN \\
Viking I & Rhizobium etli & Phaseolus vulgaris L. & CFN \\
Hambi 540 & Rhizobium galegae & Galega officinalis & HAMBI \\
CCBAU 2609 & Rhizobium huakuii & Astragalus sinicus & CCBAU \\
ATCC 14480 & Rhizobium leguminosarum bv. trifolii & Trifolium pratense & ATCC \\
ATCC 10004 & Rhizobium leguminosarum bv. viciae & Pisum sativum & ATCC \\
USDA 2489 & Rhizobium leguminosarum bv. viciae & Vicia faba & USDA \\
USDA 2445 & Rhizobium leguminosarum bv. viciae & Lathyrus latifolius & USDA \\
92A3 & Rhizobium leguminosarum bv. viciae & Lathyrus hirsutus & LiphaTech \\
L3 & Rhizobium loti & Lotus corniculatus & Agriculture Canada \\
USDA 3471 & Rhizobium loti & Lotus corniculatus & USDA \\
USDA 1002 & Rhizobium meliloti & Medicago sativa subsp. sativa & USDA \\
CFN 299 & Rhizobium tropici & Phaseolus vulgaris L. & CFN \\
CIAT 899 & Rhizobium tropici & Phaseolus vulgaris L. & CFN \\
N31 & Rhizobium sp. & Astragalus alpinus & Agriculture Canada \\
32H1 & Bradyrhizobium sp. & Crotalaria paulina & LiphaTech \\
ATCC 10324 & Bradyrhizobium japonicum & Glycine hispida & ATCC \\
\hline
\end{tabular}

a ATCC, American Type Culture Collection; USDA, U.S. Department of Agriculture, Beltsville Rhizobium Culture Collection, Beltsville, Md.; CCBAU, Culture Collection of Beijing Agricultural University, Beijing, People's Republic of China; CFN, Centro de Investigación sobre Fijación de Nitrógeno, Universidad Nacional Autónoma de México, Cuernavaca, Mexico; HAMBI, Culture Collection of the Department of Microbiology, University of Helsinki, Helsinki, Finland.

Numerical analysis of phenotypic characteristics. Strains were tested for their capacity to nodulate the following legume species: Glycine max, L. japonicus, $L$. pratensis, Lens culinaris, Lotus comiculatus, Macroptilium atropurpureum, Medicago sativa, Onobrychis viciifolia, Phaseolus vulgaris, Pisum sativum, Vicia sativa, and Vicia faba. Plants were grown in glass tubes $(25$ by $200 \mathrm{~mm})$ containing a mixture of vermiculite and nitrogen-free nutrient solution (17), except for Vicia $f a b a$, which was grown in 500-ml Erlenmeyer flasks. Seedlings were inoculated with $10^{8}$ cells of the strain to be tested, and plants were grown under a night-day temperature cycle of 15 and then $20^{\circ} \mathrm{C}$ with a 16-h light period ( 300 microeinsteins $\mathrm{m}^{-2} \mathrm{~s}^{-1}$ ). After 1 month, plants were examined for nodulation. A strain was considered positive after reisolation from nodules.

Strains were tested for their ability to utilize different substrates for growth Bacteria were grown in YM broth (23) to the mid-exponential phase, washed twice, and resuspended in $\mathrm{NaCl}(0.85 \%)$. Bacterial suspensions $\left(10^{8}\right.$ cells $\left./ \mathrm{ml}\right)$ were inoculated in triplicate with a replica plater on agar plates of minimal medium (17) containing biotin, thiamine, and pantothenic acid and the appropriate test substrate. The carbohydrates ( $1 \mathrm{~g} /$ liter each) $\mathrm{L}-(+)$-arabinose, dextrin, dulcitol, $\beta$-D-fructose, $\alpha$-D- $(+)$-fucose, $D-(+)$-galactose, glucose, glycerol, inositol, $\alpha$-lactose, maltose, mannitol, $\mathrm{D}-(+)$-mannose, $\mathrm{D}-(+)$-melibiose, raffinose, $\alpha-\mathrm{L}$-rhamnose, D-ribose, D-sorbitol, sucrose, trehalose, and D- $(+)$-xylose and the organic acids (each at 2, 10, and $20 \mathrm{mM}$ ) acetate, $\alpha$-ketoglutarate, fumarate, glyoxylate, lactate, malate, oxaloacetate, pyruvate, and succinate were each tested for utilization as the sole carbon source. When the amino acids $(0.5 \mathrm{~g} / \mathrm{liter}$ each) L-alanine, L-arginine hydrochloride, L-asparagine, L-glutamate, L-glutamine, glycine, L-histidine, L-isoleucine, L-lysine, L-methionine, L-phenylalanine, L-proline, L-serine, L-threonine, L-tryptophan, and L-valine were each tested as the sole carbon and nitrogen source, ammonium nitrate was not included in the medium. Plates were incubated at $25^{\circ} \mathrm{C}$ for 3 days, at which time the formation of colonies was recorded.

Resistance to antibiotics was tested by using cell suspensions described above and a replica plater to inoculate the surfaces of YM agar medium plates containing ampicillin $(10 \mu \mathrm{g} / \mathrm{ml})$, chloramphenicol $(10 \mu \mathrm{g} / \mathrm{ml})$, erythromycin $(10$ $\mu \mathrm{g} / \mathrm{ml})$, gentamicin $(25 \mu \mathrm{g} / \mathrm{ml})$, kanamycin $(10 \mu \mathrm{g} / \mathrm{ml})$, neomycin $(10 \mu \mathrm{g} / \mathrm{ml})$, nystatin $(2 \mu \mathrm{g} / \mathrm{ml})$, penicillin $(15 \mu \mathrm{g} / \mathrm{ml})$, rifampin $(120 \mu \mathrm{g} / \mathrm{ml})$, streptomycin $(60$ $\mu \mathrm{g} / \mathrm{ml})$, or tetracycline $(5 \mu \mathrm{g} / \mathrm{ml})$. Strains were considered resistant when growth occurred and sensitive when no growth or very poor growth occurred.

Strains were tested for their ability to grow in the presence of heavy metals. Plates containing YM agar medium supplemented with $\mathrm{CuCl}_{2} \cdot \mathrm{H}_{2} \mathrm{O}(100 \mu \mathrm{g} /$ $\mathrm{ml}), \mathrm{AlCl}_{3} \cdot 6 \mathrm{H}_{2} \mathrm{O}(500 \mu \mathrm{g} / \mathrm{ml}), \mathrm{HgCl}_{2}(5 \mu \mathrm{g} / \mathrm{ml}), \mathrm{CdCl}_{2} \cdot 2 \mathrm{H}_{2} \mathrm{O}(20 \mu \mathrm{g} / \mathrm{ml})$, $\mathrm{ZnCl}_{2}(100 \mu \mathrm{g} / \mathrm{ml})$, or $\mathrm{Pb}\left(\mathrm{CH}_{3} \mathrm{COO}\right)_{2}(500 \mu \mathrm{g} / \mathrm{ml})$ were inoculated as described above.

Growth at extreme temperatures was determined in liquid YM medium on a rotary shaker $(200 \mathrm{rpm})$ at $5^{\circ} \mathrm{C}$ for 20 days and at $32^{\circ} \mathrm{C}$ for $72 \mathrm{~h}$. At the end of incubation, protein content was determined with $1 \mathrm{ml}$ of culture by the modified version (6) of the method of Lowry.

Tolerance to $\mathrm{NaCl}$ was evaluated by determining growth on $\mathrm{YM}$ agar medium supplemented with 1 to $6 \% \mathrm{NaCl}$ after $72 \mathrm{~h}$ to 7 days of incubation at $25^{\circ} \mathrm{C}$.

Tolerance to extreme $\mathrm{pH}$ was evaluated by the capacity of strains to grow on YM agar plates adjusted to $\mathrm{pH} 2.5,3.5,5.0,6.2,7.5,8.0$, or 9.0 .

All results were analyzed using Jaccard's community coefficient and the unweighed pair group method with average (UPGMA) clustering (10).
Multilocus enzyme electrophoresis. The genetic diversity of strains was investigated by the determination of the electrophoretic types (ETs) of eight enzymes. Strains were grown for $72 \mathrm{~h}$ at $25^{\circ} \mathrm{C}$ in $100 \mathrm{ml}$ of YM medium. After centrifugation at $15,000 \times \mathrm{g}$ for $10 \mathrm{~min}$, the pellets were suspended in $2 \mathrm{ml}$ of Tris-EDTA buffer (10 mM Tris, $1 \mathrm{mM}$ EDTA, $0.5 \mathrm{mM}$ NADP, pH 6.8). The cell suspensions were sonicated twice for $20 \mathrm{~s}$ each time with a 20 -s interval between the two sonications with a sonic disintegrator (Fisher model 300) and then centrifuged at $30,000 \times g$ for $20 \mathrm{~min}$. The supernatants were stored at $-70^{\circ} \mathrm{C}$ in $10 \%$ glycerol until electrophoresis.

Polyacrylamide gel electrophoresis was performed by the method of McLellan and Ramshaw (14), and the selective staining of enzymes was done as described by Selander et al. (20). The enzymes assayed were alcohol dehydrogenase, glucose-6-phosphate dehydrogenase, NAD-glutamate dehydrogenase, hexokinase, indophenol oxidase, isocitrate dehydrogenase, NAD-malate dehydrogenase, and xanthine dehydrogenase. The electrophoresis buffer system used was Tris-citrate, $\mathrm{pH} 8.0$.

Distinctive mobility variants (ETs) of each enzyme were numbered in order of decreasing anodal mobility. Each mobility variant was equated with an allele at a structural gene locus, and the ET patterns were considered to be multilocus genotypes. The genetic diversity for an enzyme locus was calculated as follows: $h=1-\Sigma x_{i}^{2}\left[n /(n-1]\right.$, where $x_{i}$ is the frequency of the $i$ th allele and $n$ is the number of ETs. The mean genetic diversity per locus $(H)$ is the arithmetic average of $h$ values for the eight loci (20).

Cluster analysis was performed by using Gower's similarity coefficient (7) calculated by the unweighed pair group method with averages (UPGMA) (10) with the $R$ numerical analysis software package (10).

DNA-DNA hybridization homologies. Eight strains selected in each group formed by numerical analysis were used to determine DNA homology within Lathyrus populations of rhizobia and with the reference strains. DNA was extracted and purified from cells of each strain grown in YM broth. Mid-exponential-phase cultures were washed and suspended in STE buffer $(50 \mathrm{mM}$ Tris- $\mathrm{HCl}$, $50 \mathrm{mM}$ EDTA, $10 \%$ sucrose, $\mathrm{pH} 8.0$ ). Cells were lysed by incubation on ice with successive additions of lysozyme $(2.4 \mathrm{mg} / \mathrm{ml})$, pronase E $(450 \mu \mathrm{g} / \mathrm{ml})$, and $N$. lauryl sarcosinate $(0.25 \%$ [wt/vol] $)$. The lysates were subjected to serial extractions with successive equal volumes of phenol, chloroform, and ether. The DNA was precipitated first with isopropanol and then with ethanol in the presence of sodium acetate and suspended in TE buffer $(10 \mathrm{mM}$ Tris- $\mathrm{HCl}, 1 \mathrm{mM}$ EDTA, pH $8.0)$. The extract of DNA was treated with RNase $(10 \mathrm{mg} / \mathrm{ml})$ and denatured in $0.4 \mathrm{M} \mathrm{NaOH}$, and $1.5 \mu \mathrm{g}$ of the DNA free of RNA was slot blotted onto a nylon membrane (Hybond-N). Hybridization was done with DNA probes previously labelled with ${ }^{32} \mathrm{P}$ by nick translation $\left(10^{8} \mathrm{cpm} / \mathrm{mg}\right.$ of DNA) ( ${ }^{\mathrm{T} 7}$ QuickPrime Kit; Pharmacia). DNA probes were from eight reference strains (92A3, ATCC 10004, ATCC 10324, CFN 42, L3, N31, USDA 2445, and USDA 2489) and two test strains ( $\mathrm{Lj} 7$ and $\mathrm{Lp} 1006)$

Nucleotide sequences of the $16 \mathrm{~S}$ rRNA genes. The partial nucleotide sequences of the 16S ribosomal RNA (rRNA) genes of strains $\mathrm{Lj} 3$ (from $L$. japonicus) and Lp 1013 (from L. pratensis) were determined by directly sequencing double-stranded PCR products with Sequenase (U.S. Biochemical Corp.). A 310 -bp region was amplified by using a GenAmp DNA amplification reagent kit (Perkin-Elmer Cetus) with 24-mer primers. The forward primer (5'-TGGCTC AGAACGAACGCTGGCGGC-3') and the reverse primer (5'-CCCACTGCTG 
CCTCCCGTAGGAGT-3') corresponded to Escherichia coli positions 20 to 43 and 361 to 338 , respectively. The PCR was carried out as follows: 30 cycles, with 1 cycle consisting of $30 \mathrm{~s}$ at $95^{\circ} \mathrm{C}$ for denaturation, $30 \mathrm{~s}$ at $55^{\circ} \mathrm{C}$ for primer annealing, and $3 \mathrm{~min}$ at $72^{\circ} \mathrm{C}$ for extension. A hot start step preceded the first cycle and consisted of $2 \mathrm{~min}$ of denaturation at $95^{\circ} \mathrm{C}, 30 \mathrm{~s}$ at $55^{\circ} \mathrm{C}$, and $2 \mathrm{~min}$ at $72^{\circ} \mathrm{C}$ after which the polymerase was added. The products were visualized on $1 \%$ agarose gel, and the 310-bp band was excised from the gel and incubated in $1 \mathrm{ml}$ of TE buffer overnight at $4{ }^{\circ} \mathrm{C}$. This solution was used for an asymmetric PCR with three primer dilutions $(1 / 50,2 / 50$, and $3 / 50)$ to allow the amplification of a single-stranded product. The amplification was done as described above but with 35 cycles. The asymmetric PCR products were purified by using the Magic PCR Preps DNA purification system (Promega) as recommended by the manufacturer. Both strands of three to four independent single-stranded PCR products were sequenced with Sequenase (5)

The sequences were aligned with 18 known sequences of different species by using the program PILEUP (Genetics Computer Group Sequence Analysis) The following sequences were obtained from GenBank (accession number given in parentheses): Agrobacterium tumefaciens DMS 30105 (M11223), Azorhizobium caulinodans ORS 571 (M55491), Bradyrhizobium japonicum USDA 110 (M55485), Bradyrhizobium sp. strain BTAil (M55492) and NZP 2257 (M55486), $R$. etli OLIVIA (M55235), Rhizobium fredii IAM 14142 (D12796), Rhizobium huakuii IAM 14158 (D12797), $R$. leguminosarum 162Y13 (M55240), $R$. leguminosarum bv. phaseoli 8002 (M55494) and FL27 (M55234), Rhizobium loti NZP 2213 (X63823), Rhizobium meliloti ATCC 9930 (M55241) and CC169 (M55242), Rhizobium sp. (isolated from Medicago sativa and Phaseolus vulgaris) OR191 (M55236), and $R$. tropici CIAT 899 (M55233). Nucleotide sequences of $R$. leguminosarum bv. trifolii (USDA 2046) and $R$. leguminosarum bv. viciae (USDA 2370) were obtained from the U.S. Department of Agriculture. Phylogenetic relationships were determined by parsimony analysis performed with an heuristic search algorithm on all sequences followed by a 500-replication bootstrap analysis using the program PAUP (22).

Nucleotide sequence accession numbers. The ribosomal gene sequences of strain $\mathrm{Lj} 3$ isolated from $L$. japonicus and strain $\mathrm{Lp} 1013$ isolated from $L$. pratensis have been deposited in GenBank/EMBL nucleotide sequence database under the accession numbers U08100 and U08101, respectively.

\section{RESULTS}

Biochemical, physiological, and nodulation characteristics. A numerical taxonomic analysis performed on 112 characteristics divided the 79 strains of $L$. japonicus and $L$. pratensis into four distinct groups, and three strains formed three separate clusters at a similarity level of $90 \%$ (Fig. 1). The four groups were associated at a similarity level of $83 \%$.

Groups I and II comprised exclusively strains of $L$. pratensis and were related to the three unclustered strains at $85 \%$ similarity. Group I strains and the three unclustered strains differed from those of group II by their resistance to chloramphenicol and the utilization of $2 \mathrm{mM}$ acetate. Group III included five strains isolated from $L$. pratensis and three reference strains ( $R$. fredii USDA 191 and $R$. leguminosarum bv. viciae USDA 2445 and USDA 2489). Group III strains differed from those of groups I and II by their utilization of $10 \mathrm{mM}$ acetate and their resistance to erythromycin. Groups I and III differed from group II in their tolerance to chloramphenicol. Group IV included only strains of $L$. japonicus, and this group was related to group III at a $87 \%$ similarity level and to groups I and II at a $84 \%$ similarity level.

Few traits could also distinguish rhizobial strains of $L$. pratensis (groups I, II, and III) from those of L. japonicus (group IV) (Table 2). Ribose was catabolized only by strains from $L$. japonicus. In general, strains from $L$. japonicus were tolerant to copper and lead (except for one strain), while strains from $L$. pratensis (except for five strains) were not tolerant. The number of strains showing tolerance to zinc was higher in the $L$. japonicus rhizobial population (18 of 30 strains) than in the $L$. pratensis rhizobial population (5 of 49 strains). Growth at the extreme temperatures of 5 and $32^{\circ} \mathrm{C}$ clearly indicated an adaptation of the $L$. japonicus rhizobial strains to grow at low temperatures (Table 3). After 20 days of incubation at $5^{\circ} \mathrm{C}$, the majority of $L$. pratensis rhizobial strains (groups I, II, and III) grew poorly and produced 0 to $30 \mu \mathrm{g}$ of protein per ml, while half of the strains of $L$. japonicus produced more than $60 \mu \mathrm{g}$ of protein per $\mathrm{ml}$ (Table 2). At this low temperature, the mean growth yield of the reference strains was significantly lower than that of both populations, suggesting that some strains of $L$. pratensis were also cold adapted (Table 3 ). At $32^{\circ} \mathrm{C}$, the average growth yield of rhizobia from $L$. japonicus was not significantly different from that of rhizobia from $L$. pratensis and from that from reference strains. However, at this temperature many rhizobial strains (13 of 30) from $L$. japonicus had a greater yield ( 30 to $60 \mu \mathrm{g}$ of protein per $\mathrm{ml}$ ) than the majority of rhizobial strains (30 of 49 ) from L. pratensis $(<30$ $\mu \mathrm{g}$ of protein per $\mathrm{ml}$ ) (Table 2 ).

Among the reference strains not included in the groups, the three strains $R$. leguminosarum bv. viciae ATCC 10004 and $92 \mathrm{~A} 3$ and $R$. leguminosarum bv. trifolii ATCC 14480 were closely related to the four groups at 82,77 , and $75 \%$ similarity levels, respectively. The slow-growing reference strains $B$. japonicum ATCC 10324 and Rhizobium sp. strain 32H1 (isolated from Crotalaria paulina) showed the lowest similarity levels (47 and $36 \%$, respectively) with the Lathyrus rhizobia.

Although strains could be subdivided according to their plant origin (L. pratensis or L. japonicus) by the numerical taxonomic analysis, they shared many similar phenotypic characteristics (Table 2). All strains from the two Lathyrus species formed mucoid colonies on YM agar, were motile, and could grow at pH 5.0 to 9.0 (except for three strains). All strains were able to use 14 different sugars as the sole carbon source, and none could use dextrine and fucose. All strains also showed similar utilization of the organic acids fumarate $(2,10$, and 20 $\mathrm{mM})$, malate $(2 \mathrm{mM})$, pyruvate $(2$ and $20 \mathrm{mM})$, and succinate $(10 \mathrm{mM})$, while acetate $(20 \mathrm{mM}), \alpha$-ketoglutarate, glyoxylate, lactate, malate $(10$ and $20 \mathrm{mM})$, and oxaloacetate (10 and 20 $\mathrm{mM}$ ) were not utilized. They were resistant to ampicillin, nystatin, and penicillin and sensitive to neomycin and rifampin. Sensitivity to the heavy metals aluminium, cobalt, and mercury was observed for all strains. All strains failed to grow on medium containing $1 \% \mathrm{NaCl}$, except one which could grow in the presence of $3 \% \mathrm{NaCl}$.

Both populations of rhizobia isolated from the two Lathyrus species could nodulate $L$. pratensis and $L$. japonicus, as well as Lens culinaris, all legume species belonging to the tribe Viciae (Table 2). Among the other legume species from this tribe, Vicia sativa was nodulated by all strains from $L$. pratensis and by $90 \%$ of strains from L. japonicus; Vicia faba was nodulated by the majority of strains from $L$. pratensis but by only $14 \%$ of strains from L. japonicus; Pisum sativum was nodulated by only one strain. None of the strains could nodulate Medicago sativa, and only $66 \%$ of isolates from L. japonicus could nodulate Trifolium pratense (tribe Trifolieae). None of the strains nodulated members of the tribes Phaseoleae and Hedysareae, and very few strains nodulated Lotus corniculatus (tribe Loteae).

Multilocus enzyme electrophoresis. For rhizobial strains isolated from $L$. japonicus and $L$. pratensis and for reference strains, 78 ETs were observed when eight enzymes were used. A mean of nine alleles was observed per enzyme, while only five alleles were detected among Lathyrus rhizobial strains (Table 4). A single allele profile was observed for alcohol dehydrogenase in strains from $L$. pratensis and for isocitrate dehydrogenase in strains from $L$. japonicus. Although the number of ETs was lower for strains of $L$. japonicus (21 ETs) than those of $L$. pratensis (40 ETs), the mean genetic diversity was identical between the two populations with a value of 0.451 . At a genetic distance of 0.55 , eight groups of ETs were identified by cluster analysis (Fig. 2). The majority of strains (40 of 49) from $L$. pratensis were included in group II, which also com- 
$\%$ of similarity

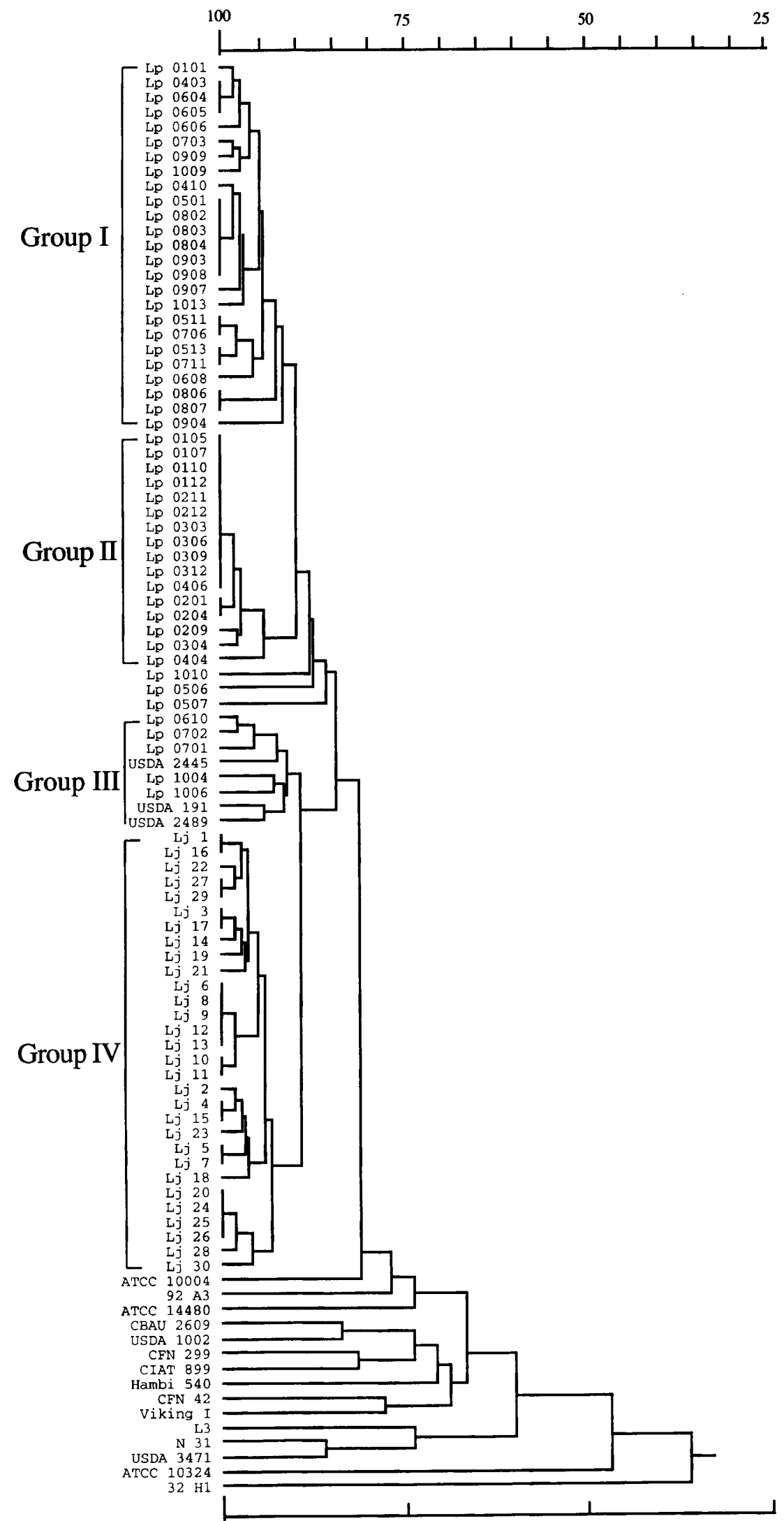

FIG. 1. Dendrogram showing the relationships among Lathyrus rhizobial strains, based on physiological, biochemical, and nodulation characteristics. Lp, $L$. pratensis; $\mathrm{Lj}, L$. japonicus. 
TABLE 2. Phenotypic characteristics of rhizobia isolated from Lathyrus japonicus and Lathyrus pratensis

\begin{tabular}{|c|c|c|c|c|}
\hline \multirow{3}{*}{ Characteristic } & \multicolumn{4}{|c|}{ Value or result for group ${ }^{a}$} \\
\hline & \multicolumn{3}{|c|}{ L. pratensis } & \multirow{2}{*}{$\begin{array}{l}\text { L. japonicus } \\
\text { group IV }\end{array}$} \\
\hline & $\begin{array}{l}\text { Group } \\
\text { I }\end{array}$ & $\begin{array}{l}\text { Group } \\
\text { II }\end{array}$ & $\begin{array}{l}\text { Group } \\
\text { III }\end{array}$ & \\
\hline No. of strains & 25 & 19 & 5 & 30 \\
\hline \multicolumn{5}{|l|}{ Growth on: } \\
\hline Acetate $(2 \mathrm{mM})$ & + & 3 & + & + \\
\hline Acetate $(10 \mathrm{mM})$ & 5 & - & + & + \\
\hline Acetate $(20 \mathrm{mM})$ & - & - & - & - \\
\hline $\begin{array}{l}\alpha \text {-Ketoglutarate }(2,10 \text {, and } \\
20 \mathrm{mM})\end{array}$ & - & - & - & - \\
\hline Fumarate $(2,10$, and $20 \mathrm{mM})$ & + & + & + & + \\
\hline Glyoxylate $(2,10$, and $20 \mathrm{mM})$ & - & - & - & - \\
\hline Lactate $(2,10$, and $20 \mathrm{mM})$ & - & - & - & - \\
\hline Malate $(2 \mathrm{mM})$ & + & + & + & + \\
\hline Malate $(10$ and $20 \mathrm{mM})$ & - & - & - & - \\
\hline Oxaloacetate $(2 \mathrm{mM})$ & + & + & 4 & + \\
\hline Oxaloacetate (10 and $20 \mathrm{mM})$ & - & - & - & - \\
\hline Pyruvate $(2 \mathrm{mM})$ & + & + & + & + \\
\hline Pyruvate $(10 \mathrm{mM})$ & 22 & 18 & + & + \\
\hline Pyruvate $(20 \mathrm{mM})$ & + & + & + & + \\
\hline Succinate $(2 \mathrm{mM})$ & + & + & 4 & + \\
\hline Succinate $(10 \mathrm{mM})$ & + & + & + & + \\
\hline Succinate $(20 \mathrm{mM})$ & + & 16 & + & + \\
\hline Arabinose & 24 & 18 & + & + \\
\hline Dextrin & - & - & - & - \\
\hline Dulcitol & + & + & + & + \\
\hline Fructose & + & + & + & + \\
\hline Fucose & - & - & - & - \\
\hline Galactose & + & + & + & + \\
\hline Glucose & + & + & + & + \\
\hline Glycerol & + & + & + & + \\
\hline Inositol & + & 18 & + & + \\
\hline Lactose & + & + & + & + \\
\hline Maltose & + & + & + & + \\
\hline Mannitol & + & + & + & + \\
\hline Mannose & + & + & + & + \\
\hline Melibiose & + & + & + & 28 \\
\hline Raffinose & + & + & + & + \\
\hline Rhamnose & + & + & + & + \\
\hline Ribose & - & - & - & + \\
\hline Sorbitol & + & + & + & + \\
\hline Sucrose & + & + & + & + \\
\hline Trehalose & + & + & + & + \\
\hline Xylose & + & + & + & + \\
\hline Alanine & + & + & + & + \\
\hline Arginine & + & + & + & + \\
\hline Asparagine & - & - & - & - \\
\hline Glutamate & + & + & + & + \\
\hline Glutamine & + & + & + & + \\
\hline Glycine & - & - & - & - \\
\hline Histidine & + & + & + & + \\
\hline Isoleucine & - & - & - & - \\
\hline Leucine & - & - & - & - \\
\hline Lysine & - & - & - & - \\
\hline Methionine & - & - & - & - \\
\hline Phenylalanine & - & - & - & - \\
\hline Proline & + & + & + & + \\
\hline Serine & - & - & 1 & - \\
\hline Threonine & - & - & - & - \\
\hline Valine & - & - & - & - \\
\hline \multicolumn{5}{|l|}{ Resistance to: } \\
\hline Ampicillin & + & + & + & + \\
\hline Chloramphenicol & + & 3 & + & 14 \\
\hline Erythromycin & - & - & 3 & 7 \\
\hline
\end{tabular}

TABLE 2-Continued

\begin{tabular}{|c|c|c|c|c|}
\hline \multirow{3}{*}{ Characteristic } & \multicolumn{4}{|c|}{ Value or result for group ${ }^{a}$} \\
\hline & \multicolumn{3}{|c|}{ L. pratensis } & \multirow{2}{*}{$\begin{array}{l}\text { L. japonicus } \\
\text { group IV }\end{array}$} \\
\hline & $\begin{array}{c}\text { Group } \\
\text { I }\end{array}$ & $\begin{array}{c}\text { Group } \\
\text { II }\end{array}$ & $\begin{array}{c}\text { Group } \\
\text { III }\end{array}$ & \\
\hline Gentamicin & - & 1 & - & - \\
\hline Kanamycin & 13 & 6 & + & + \\
\hline Neomycin & - & - & - & - \\
\hline Nystatin & + & + & + & + \\
\hline Penicillin & + & + & + & + \\
\hline Rifampin & - & - & - & - \\
\hline Streptomycin & - & 1 & - & 7 \\
\hline Tetramycin & - & 1 & 1 & - \\
\hline \multicolumn{5}{|l|}{ Tolerance to: } \\
\hline Aluminium & - & - & - & - \\
\hline Cobalt & 1 & - & - & - \\
\hline Copper & 2 & 1 & 2 & + \\
\hline Lead & 2 & 2 & - & + \\
\hline Mercury & 2 & - & 1 & - \\
\hline Zinc & 2 & 1 & 1 & 18 \\
\hline $\mathrm{NaCl}(1 \%)$ & - & 1 & - & - \\
\hline $\mathrm{NaCl}(2 \%)$ & - & 1 & - & - \\
\hline $\mathrm{NaCl}(3 \%)$ & - & 1 & - & - \\
\hline \multicolumn{5}{|l|}{ Growth at: } \\
\hline $\mathrm{pH} 3.0$ & - & - & - & - \\
\hline $\mathrm{pH} 4.0$ & - & - & - & - \\
\hline pH 5.0 & 23 & + & + & + \\
\hline pH 5.7 & 23 & + & + & + \\
\hline $\mathrm{pH} 6.2$ & + & + & + & + \\
\hline $\mathrm{pH} 6.9$ & + & + & + & + \\
\hline pH 7.2 & + & + & + & + \\
\hline pH 8.0 & + & + & + & + \\
\hline $\mathrm{pH} 9.0$ & 24 & + & + & + \\
\hline $5^{\circ} \mathrm{C}(<30 \mathrm{mg}$ of protein $)$ & 20 & + & 2 & 1 \\
\hline $5^{\circ} \mathrm{C}(31-60 \mathrm{mg}$ of protein) & 3 & - & 2 & 14 \\
\hline $5^{\circ} \mathrm{C}(>60 \mathrm{mg}$ of protein $)$ & 2 & - & 1 & 15 \\
\hline $32^{\circ} \mathrm{C}(<30 \mathrm{mg}$ of protein $)$ & 17 & 10 & 3 & 9 \\
\hline $32^{\circ} \mathrm{C}(31-60 \mathrm{mg}$ of protein) & 8 & 9 & 2 & 21 \\
\hline $32^{\circ} \mathrm{C}(>60 \mathrm{mg}$ of protein) & - & - & - & - \\
\hline
\end{tabular}

Host nodulation response Tribe Vicieae

Lathyrus japonicus
Lathyrus pratensis
Lens culinaris
Pisum sativum
Vicia faba
Vicia sativa

Tribe Trifolieae

Trifolium pratense

Medicago sativa

Tribe Phaseoleae

Phaseolus vulgaris

Macroptillium atropurpureum

Glycine max

Tribe Hedysareae

Onobrychis viciifolia

Tribe Loteae

Lotus corniculatus

$$
3 \quad-\quad 1
$$

${ }^{a}$ The numbers shown are the numbers of positive strains. Symbols:,$+ 95 \%$ or more of strains are positive;,$- 95 \%$ or more of strains are negative. 
TABLE 3. Average growth yields at extreme temperatures for strains isolated from Lathyrus japonicus and Lathyrus pratensis and closely related strains

\begin{tabular}{lcc}
\hline \multicolumn{1}{c}{ Group of strains } & \multicolumn{1}{c}{$\begin{array}{c}\text { Avg growth yield } \\
\left(\mu \mathrm{g} \text { of protein } \cdot \mathrm{ml}^{-1}\right) \\
\text { the following temp }\end{array}$} \\
\cline { 2 - 3 } & $\begin{array}{c}5^{\circ} \mathrm{C}(20 \text { days } \\
\text { of growth) }\end{array}$ & $\begin{array}{l}32^{\circ} \mathrm{C}(24 \mathrm{~h} \\
\text { of growth) }\end{array}$ \\
\hline Groups I, II, and III (L. pratensis) & $18.7 \mathrm{a}$ & $27.4 \mathrm{a}$ \\
Group IV (L. japonicus) & $63.5 \mathrm{~b}$ & $37.5 \mathrm{ab}$ \\
Reference strains (ATCC 10004, & $1.4 \mathrm{c}$ & $47.9 \mathrm{~b}$ \\
92A3, ATCC 14480, USDA 191, & & \\
USDA 2445, and USDA 2489) & & \\
\hline
\end{tabular}

${ }^{a}$ Means within a column followed by the same letter are not significantly different at $P<0.05$ by the Duncan multiple-range test.

${ }^{b}$ The reference strains are Rhizobium leguminosarum bv. viciae ATCC 10004, $R$. leguminosarum bv. viciae $92 \mathrm{~A} 3$ (Lathyrus hirsutus), $R$. leguminosarum bv. trifolii ATCC 14480, Rhizobium fredii USDA 191, $R$. leguminosarum bv. viciae USDA 2445, and R. leguminosarum bv. viciae USDA 2489.

prised half of the rhizobial strains (15 of 30) from L. japonicus. All other strains were distributed among all groups, except for groups V, VII, and VIII which comprised only reference strains. Other reference strains were distributed in groups III, IV, and VI. The five reference strains of $R$. leguminosarum were included in groups III and IV and were related to groups I and II (Lathyrus rhizobial strains) at a genetic distance of 0.68 . Strains of $R$. tropici were included in group VI, which was related to previous groups at a genetic distance of 0.75 . Reference strains from group VIII, composed of $R$. fredii USDA 191, Rhizobium sp. strain 32H1 (isolated from Crotalaria paulina), and $B$. japonicum ATCC 10324 were the most distant, with branching at 0.86 .

DNA-DNA hybridization homologies. The three rhizobial strains isolated from $L$. japonicus and the five strains isolated from $L$. pratensis showed relatively high levels of DNA homology (61 to $100 \%)$ with each of their two homologous probes $(\mathrm{Lj}$ 7 from L. japonicus and Lp 1006 from L. pratensis), indicating an homogeneity among Lathyrus rhizobial strains (Table 5). DNAs from four reference strains of $R$. leguminosarum bv. viciae (92A3, ATCC 10004, USDA 2445, and USDA 2489) exhibited high levels of hybridization with DNAs from all $\mathrm{La}$ thyrus rhizobial strains tested. Homology levels were very low between Lathyrus rhizobial strains and other reference strains belonging to different species of Rhizobium.

Nucleotide sequences of the 16S rRNA gene. The partial 16S rRNA gene sequences of strain $\mathrm{Lj} 3$ (L. japonicus) and strain Lp 1013 (L. pratensis) were compared with 18 partial sequences of members of the family Rhizobiaceae, including five sequences from $R$. leguminosarum. Figure 3 shows the general structure of a phylogenic tree obtained by the heuristic search, which produced four trees with an equal length of 106 base modifications. The calculations were done by defining an outgroup which encompassed Azorhizobium caulinodans ORS 571 and all three Bradyrhizobium sequences to allow the rooting of the tree. The tree formed two clades: one included Azorhizobium and Bradyrhizobium strains, and the other contained all Rhizobium strains including the two strains isolated from Lathyrus species. Sequences of strain $\mathrm{Lj} 3$ from $L$. japonicus were identical to those of one strain of $R$. leguminosarum bv. trifolii, one strain of $R$. leguminosarum bv. phaseoli and one strain of $R$. leguminosarum bv. viciae. Sequences of strain Lp 1013 from L. pratensis differed by 2 nucleotides from those grouping $\mathrm{Lj} 3$ with the $R$. leguminosarum strains.

\section{DISCUSSION}

The phenotypic and genotypic characterization of rhizobia isolated from $L$. japonicus and $L$. pratensis, two legume species indigenous to northern Quebec, allowed us to classify them as $R$. leguminosarum bv, viciae. This result confirms earlier studies in which rhizobia from Lathyrus species were classified as $R$. leguminosarum because they showed phenotypic and nodulation characteristics similar to those of rhizobia from other legume species belonging to the tribe Vicieae (Pisum, Vicia, and Lens) (1). In our study, physiological characteristics of Lathyrus rhizobia such as the inability to grow on $1 \% \mathrm{NaCl}$ (except for one strain) and to use $20 \mathrm{mM}$ citrate or lactate as the sole carbon source are similar to other strains of $R$. leguminosarum (9). Host plant nodulation range, which is the basis for the identification of biovars in $R$. leguminosarum, is typical of that reported for $R$. leguminosarum biovar viciae (9); the majority of Lathyrus rhizobial strains nodulated Lens culinaris and Vicia sativa of the tribe Vicieae.

Cluster analysis of genotypic characteristics (ET) and levels

TABLE 4. Characteristics of genetic diversity at the loci coding for eight enzymes in the ETs observed in rhizobial strains isolated from Lathyrus species

\begin{tabular}{|c|c|c|c|c|c|c|c|c|}
\hline \multirow{2}{*}{ Enzyme locus ${ }^{a}$} & \multicolumn{2}{|c|}{$\begin{array}{l}\text { All strains tested }{ }^{b} \\
\text { (78 ETs) }\end{array}$} & \multicolumn{2}{|c|}{$\begin{array}{l}\text { Strains from both Lathyrus } \\
\text { species (60 ETs) }\end{array}$} & \multicolumn{2}{|c|}{$\begin{array}{c}49 \text { strains from } L . \text { pratensis } \\
\text { (40 ETs) }\end{array}$} & \multicolumn{2}{|c|}{$\begin{array}{l}30 \text { strains from } L . \text { japonicus } \\
\text { (21 ETs) }\end{array}$} \\
\hline & No. of alleles & $h^{c}$ & No. of alleles & $h$ & No. of alleles & $h$ & No. of alleles & $h$ \\
\hline ADH & 9 & 0.349 & 3 & 0.144 & 1 & 0.000 & 3 & 0.343 \\
\hline GDH & 10 & 0.531 & 5 & 0.403 & 3 & 0.376 & 5 & 0.455 \\
\hline G6PH & 7 & 0.779 & 6 & 0.746 & 5 & 0.678 & 4 & 0.609 \\
\hline HEX & 16 & 0.867 & 9 & 0.824 & 8 & 0.781 & 3 & 0.549 \\
\hline IPO & 9 & 0.634 & 7 & 0.535 & 6 & 0.510 & 3 & 0.545 \\
\hline IDH & 5 & 0.247 & 3 & 0.099 & 3 & 0.156 & 1 & 0.000 \\
\hline $\mathrm{MDH}$ & 6 & 0.658 & 4 & 0.623 & 4 & 0.701 & 4 & 0.444 \\
\hline $\mathrm{XDH}$ & 6 & 0.568 & 4 & 0.511 & 3 & 0.405 & 4 & 0.660 \\
\hline Mean & 9 & 0.579 & 5 & 0.485 & 4 & 0.451 & 3 & 0.451 \\
\hline
\end{tabular}

${ }^{a}$ Abbreviations: ADH, alcohol dehydrogenase; GDH, NAD-glutamate dehydrogenase; G6PH, glucose-6-phosphate dehydrogenase; HEX, hexokinase; IPO, indo-

phenol oxidase; IDH, isocitrate dehydrogenase; MDH, NAD-malate dehydrogenase; XDH, xanthine dehydrogenase.

${ }^{b}$ Reference strains and strains from both Lathyrus species.

c Genetic diversity; $h=1-\Sigma x_{i}^{2}\left[n /(n-1]\right.$, where $x_{i}$ is the frequency of the $i$ th allele and $n$ is the number of ETs. 


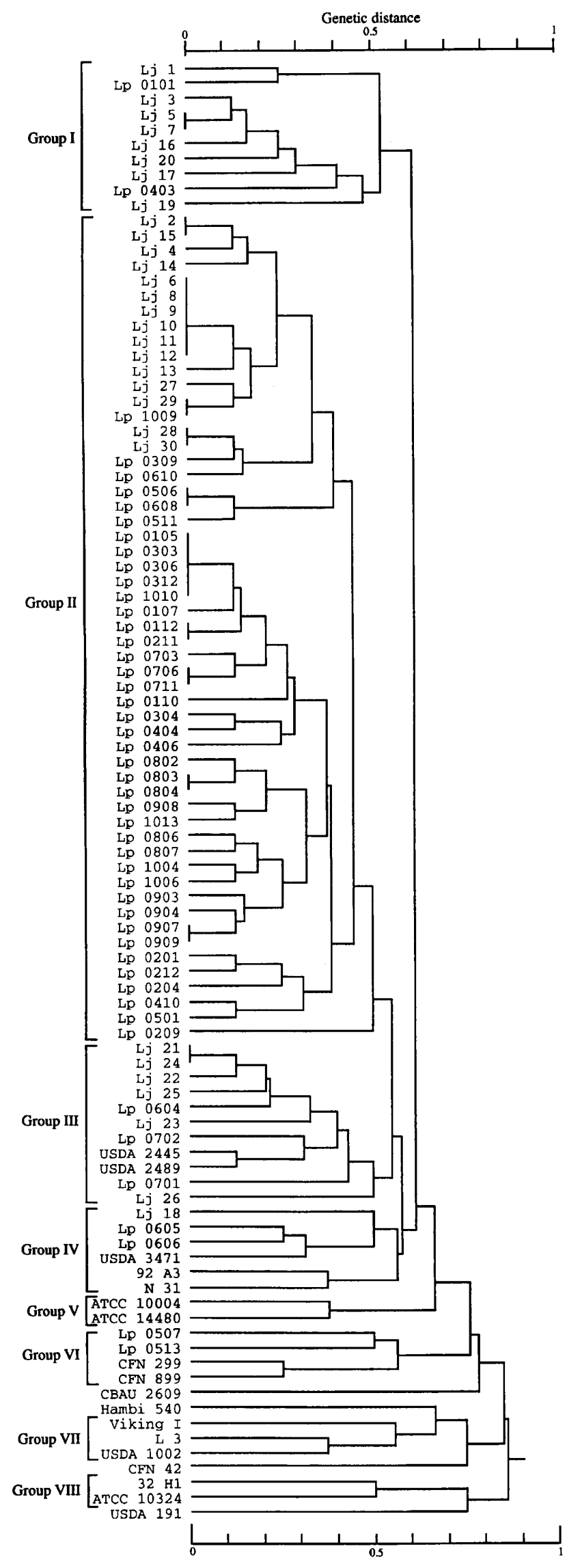

of DNA homology also showed a close relationship between reference strains of $R$. leguminosarum bv. viciae and strains of $L$. pratensis or $L$. japonicus. Comparison of partial sequences from the 16S rRNA gene revealed identity between sequences of strain $\mathrm{Lj} 3$ (L. japonicus) and those of three strains of $R$. leguminosarum (bv. phaseoli, trifolii, and viciae). Sequences of strain Lp 1013 (L. pratensis) differed by 2 nucleotides from those of strain $\mathrm{Lj} 3$, but such slight differences were also found between other strains of $R$. leguminosarum as shown in the phylogram (Fig. 3). Overall, the results demonstrate that rhizobial strains isolated from Lathyrus species belong to $R$. leguminosarum bv. viciae.

The distinction between the two populations composed of 49 strains of rhizobia isolated from $L$. pratensis and 30 strains from $L$. japonicus was not reflected by the genetic diversity which was identical for each population $(0.45)$, even though the number of ETs observed among strains from $L$. japonicus was lower than that among strains from $L$. pratensis. Two populations of $R$. leguminosarum bv. viciae found in two Oregon soils under different Vicia species also showed similar genetic diversities ( 0.49 and 0.51$)$ (21). The two rhizobial populations from Lathyrus species were also similar in many phenotypic characteristics such as growth morphology, the utilization of carbohydrates and organic acids, and the nodulation patterns. The patterns of intrinsic antibiotic resistance were not specific to either of the two populations isolated from different soil conditions. This contrasts with a study of the diversity of $R$. leguminosarum bv. viciae from two different microclimates where the intrinsic antibiotic resistance of isolates was reported to be related to topographic position (4). However, in our study, few phenotypic traits could differentiate the two populations, although they could be separated by numerical analysis. The three distinct groups formed by $L$. pratensis rhizobial strains suggest a greater variability among $L$. pratensis rhizobial strains than among $L$. japonicus rhizobial strains which formed one group with less than $10 \%$ phenotypic differences. Strains from L. japonicus were more likely to grow in the presence of copper and lead and grew better at 5 and $32^{\circ} \mathrm{C}$ than those from $L$. pratensis. Differences in growth characteristics might be attributed to the adaptation of $L$. japonicus to the harsh environment of Hudson's Bay, located in the arctic zone, where the site of collection, a sandy beach, is subject to sharp temperature gradients during the growing season and over the year. Strains from L. pratensis, an introduced legume in the boreal region of Abitibi, were less adapted to low temperatures, but they still grew better than reference strains from temperate regions. Previous studies also indicated that rhizobia from a Canadian arctic zone were cold adapted for growth and nitrogen fixation (16). These arctic rhizobia (from Astragalus and Oxytropis spp.) and the strains of Lathyrus of the present study do not constitute a specific species because of their cold adaptation. In fact, most rhizobia from Astragalus and Oxytropis spp. of different geographic origins were classified in 16S rRNA gene types similar to or closely related to $R$. loti and Rhizobium ciceri (18), and these species, as well as $R$. leguminosarum bv. viciae, are widely found in temperate areas.

The ability of $L$. japonicus rhizobial strains to tolerate various metals requires further investigation. Metal concentrations in sampled soils were not determined. We can suppose that

FIG. 2. Dendrogram showing levels of genetic distance among Lathyrus rhizobial strains and reference strains based on electrophoretically detectable allelic variation at the loci encoding eight enzymes. $\mathrm{Lj}$, L. japonicus; $\mathrm{Lp}, L$. pratensis. 
TABLE 5. DNA-DNA relatedness between Lathyrus rhizobial strains and reference strains

\begin{tabular}{|c|c|c|c|c|c|c|c|c|}
\hline \multirow{2}{*}{ Strain used as probe } & \multicolumn{8}{|c|}{ DNA-DNA relatedness $(\%)$ of the strain tested } \\
\hline & $\mathrm{Lj} 3$ & $\mathrm{Lj} 7$ & $\operatorname{Lj} 29$ & Lp 0110 & Lp 0702 & Lp 0904 & Lp 1006 & Lp 1013 \\
\hline Lp 1006 & 100 & 67 & 61 & 100 & 100 & 75 & 100 & 100 \\
\hline $\operatorname{Lj} 7$ & 100 & 100 & 91 & 100 & 98 & 90 & 82 & 100 \\
\hline R. etli CFN 42 & 44 & 31 & 26 & 49 & 39 & 27 & 33 & 30 \\
\hline R. fredii USDA 191 & 9 & 28 & 19 & 30 & 33 & 17 & 25 & 30 \\
\hline R. galegae HAMBI 540 & & 23 & & & & & 37 & \\
\hline R. leguminosarum bv. viciae $92 \mathrm{~A} 3$ & 95 & 89 & 74 & 87 & 71 & 84 & 76 & 81 \\
\hline R. leguminosarum bv. viciae ATCC 10004 & 92 & 87 & 53 & 85 & 77 & 79 & 49 & 91 \\
\hline R. leguminosarum bv. viciae USDA 2489 & 88 & 57 & 82 & 88 & 80 & 69 & 61 & 91 \\
\hline R. leguminosarum bv. viciae USDA 2445 & 95 & 64 & 93 & 100 & 100 & 90 & 75 & 93 \\
\hline R. loti $\mathrm{L} 3$ & 31 & 27 & 43 & 41 & 48 & 37 & 44 & 51 \\
\hline R. meliloti USDA 1002 & 44 & 34 & 33 & 39 & 42 & 36 & 45 & 49 \\
\hline R. tropici CIAT 899 & & 28 & & & & & 27 & \\
\hline Rhizobium sp. strain N31 & 15 & 25 & 13 & 13 & 22 & 19 & 18 & 31 \\
\hline B. japonicum ATCC 10324 & 13 & 11 & 19 & 9 & 15 & 21 & 12 & 16 \\
\hline
\end{tabular}

these strains possess operative mechanisms for detoxification, as was suggested for an arctic Rhizobium strain (2).

Although rhizobial strains isolated from $L$. japonicus and L. pratensis share genotypic and phenotypic characteristics typical of reference strains of $R$. leguminosarum bv. viciae, they differ in their capacity to grow at low temperatures. This cold adaptation is worthy of further investigation with respect to the improvement of nitrogen fixation under cool climates and for studies on the mechanisms of cold adaptation. A study system composed of two strains of $R$. leguminosarum biovar viciae differing only in their adaptation to temperature would have the potential to allow the identification of genes involved in cold adaptation.

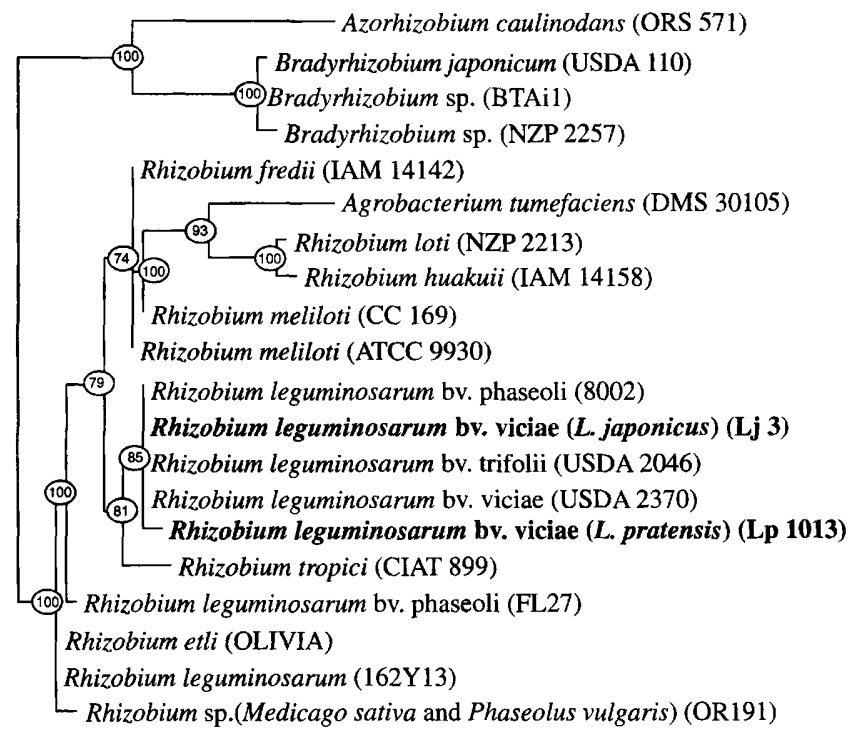

FIG. 3. Phylogenetic tree derived from partial 16S rRNA gene sequences for strains Lj 3 (L. japonicus) and strain Lp 1013 (L. pratensis) and related bacteria. Sequences were compared by parsimony analysis to form the trees. Tree number 1 is presented and was verified by consensus. The circled numbers represent the number of times (percentage) the group consisting of the strains which are to the right of the fork occurred among 500 replications in a bootstrap analysis. The sequence accession numbers of the related rhizobia can be found in Materials and Methods. Tree length (total base modifications), $106 \mathrm{bp}$; consistency index, 0.821 .

\section{ACKNOWLEDGMENTS}

We thank Peter van Berkum and Eden Bromfield for critical reading of the manuscript and Léon Lambert for technical help.

Financial support for this research was provided by research operating grant OG0121430 from the National Sciences and Engineering Research Council of Canada.

\section{REFERENCES}

1. Allen, O. N., and E. K. Allen. 1981. The Leguminosae. University of Wisconsin Press, Madison.

2. Appanna, V. D. 1991. Impact of heavy metals on an arctic rhizobium. Bull. Environ. Contam. Toxicol. 46:450-455.

3. Biederbeck, V. O., O. T. Bouman, J. Looman, A. E. Slinkard, L. D. Bailey, W. A. Rice, and H. H. Janzen. 1993. Productivity of four annual legumes green manure in dryland cropping systems. Agron. J. 85:1035-1043.

4. Brockman, F. J., and D. F. Bezdicek. 1989. Diversity within serogroups of Rhizobium leguminosarum biovar viciae in the Palouse region of Eastern Washington as indicated by plasmid profile, intrinsic antibiotic resistance, and topography. Appl. Environ. Microbiol. 55:109-115.

5. Casanova, J.-L., C. Pannetier, C. Jaulin, and P. Kourilsky. 1990. Optima conditions for directly sequencing double-stranded PCR products with sequenase. Nucleic Acids Res. 18:4028.

6. Daniels, L., R. S. Hanson, and J. A. Phillips. 1994. Chemicals analysis, p. 542. In P. Gerhardt, R. G. E. Murray, W. A. Wood, and N. R. Krieg (ed.) Methods for general and molecular bacteriology. American Society for Microbiology, Washington, D.C.

7. Gower, J. C. 1971. A general coefficient of similarity and some of its properties. Biometrics 27:857-871.

8. Graham, P. H., M. J. Sadowsky, H. H. Keyser, Y. M. Barnet, R. S. Bradley, J. E. Cooper, D. J. De Ley, B. D. W. Jarvis, E. B. Roslycky, B. W. Strijdom, and J. P. W. Young. 1991. Proposed minimal standards for the description of new genera and species of root- and stem-nodulating bacteria. Int. J. Syst. Bacteriol. 41:582-587.

9. Jordan, D. C. 1984 . Family III. Rhizobiaceae Conn $1938,321^{\mathrm{AL}}$, p. $234-256$ In N. R. Krieg and J. G. Holt (ed.), Bergey's manual of systematic bacteriology. Williams \& Wilkins, Baltimore.

10. Legendre, L., and P. Legendre. 1984. Ecologie numérique. 2. La structure des données écologiques, 2nd ed. Presse de l'Université du Québec, Québec, Canada.

11. Marie-Victorin, F. E. C. 1995 . Flore laurentienne, 3rd ed. Les presses de l'Université de Montréal, Montréal.

12. Martínez, E., M. Flores, S. Brom, D. Romero, G. Davila, and R. Palacios. 1988. Rhizobium phaseoli: a molecular genetics view. Plant Soil 108:179-184.

13. Martínez-Romero, E., L. Segovia, F. M. Mercante, A. A. Franco, P. Graham, and M. A. Pardo. 1991. Rhizobium tropici, a novel species nodulating Phaseolus vulgaris L. beans and Leucaena sp. trees. Int. J. Syst. Bacteriol. 41:417426.

14. McLellan, T., and J. A. M. Ramshaw. 1981. Serial electrophoretic transfers: a technique for the identification of numerous enzymes from single polyacrylamide gels. Biochem. Genet. 19:647-654.

15. Morisset, J., and S. Payette. 1991. Flore du Québec nordique. Presses de l'Université Laval, Québec, Canada.

16. Prévost, D., H. Antoun, and L. M. Bordeleau. 1987. Effects of low temperatures on nitrogenase activity in sainfoin (Onobrychis viciifolia) nodulated by 
arctic rhizobia. FEMS Microbiol. Ecol. 45:205-210.

17. Prévost, D., L. M. Bordeleau, S. Caudry-Reznick, H. M. Schulman, and H. Antoun. 1987. Characteristics of rhizobia isolated from three legumes indigenous to the Canadian high arctic: Astragalus alpinus, Oxytropis maydelliana, and Oxytropis arctobia. Plant Soil 98:313-324.

18. Prévost, D., G. Laguerre, P. Van Berkum, and N. Amarger. 1995. Phylogenetic position of rhizobia isolated from various Astragalus and Oxytropis species, abstr. P4. In Abstracts of the 15th North American Conference on Symbiotic Nitrogen Fixation. North Carolina State University, Raleigh.

19. Segovia, L., J. P. W. Young, and E. Martínez-Romero. 1993. Reclassification of American Rhizobium leguminosarum biovar phaseoli type I strains as Rhizobium etli sp. nov. Int. J. Syst. Bacteriol. 43:374-377.

20. Selander, R. K., D. A. Caugant, H. Ochman, J. M. Musser, M. N. Gilmour, and T. S. Whittam. 1986. Methods of multilocus enzyme electrophoresis for bacterial population genetics and systematics. Appl. Environ. Microbiol. 51:873-884.

21. Strain, S. R., K. Leung, T. S. Whittam, F. J. de Bruijn, and P. J. Bottomley. 1994. Genetic structure of Rhizobium leguminosarum biovar trifolii and viciae populations found in two Oregon soils under different plant communities. Appl. Environ. Microbiol. 60:2772-2778.

22. Swofford, D. L. 1993. PAUP: phylogenetic analysis using parsimony, version 3.1. Center for Biodiversity, Illinois Natural History Survey, Champaign, Ill.

23. Vincent, J. M. 1970. A manual for the practical study of root nodules, IBP Handbook 15. Blackwell Scientific Publications, Oxford.

24. Wright, S. F. 1985. Germination, nodulation and early growth response of a hard-seeded legume, Lathyrus sylvestris L. (flatpea). Plant Soil 88:455-459. 